\title{
HISTOLOGICAL STUDY OF THE IMMUNE SYSTEM IN ZEBRAFISH, DANIO RERIO (HAMILTON, 1822)
}

Azin AZAR * and Zahra KHOSHNOOD **

* Department of Biology, Dezful Branch, Islamic Azad University, Dezful, Iran, azinazar6@gmail.com ** Department of Biology, Dezful Branch, Islamic Azad University, Dezful, Iran, zkhoshnood@gmail.com

DOI: 10.2478/trser-2021-0011

KEYWORDS: Zebrafish, histology, immune system.

\section{ABSTRACT}

The aim of the present study was to investigate the cellular characteristics of the immune tissues of Zebrafish, Danio rerio (Hamilton, 1822). The fish were fixed in Bouin's solution for 24 hours then dehydrated, cleared, paraffinized, embedded and finally sectioned, stained and observed through optical microscopy. Results showed that immune system tissues of Zebrafish include the apical part of the kidney, thymus, and spleen. The apical part of the kidney was composed of hematopoietic tissue containing blood and immune cells. The spleen was a single organ located at the abdominal cavity containing melanomacrophages. The thymus was observed as a paired organ at the posterior part of the branchial cavity. Results showed that the immune system of the Zebrafish was dispersed in several organs of the body and that this species could be used as a laboratory model organism in immune system studies.

RÉSUMÉ: Étude histologique du système immunitaire chez Zebrafish, Danio rerio (Hamilton, 1822).

Le but de la présente étude était d'étudier les caractéristiques cellulaires des tissus immunitaires du poisson zèbre, Danio rerio (Hamilton, 1822). Les poissons ont été fixés dans la solution de Bouin pendant 24 h puis déshydratés, clarifiés, paraffinés, inclus et finalement sectionnés et colorés et observés par microscopie optique. Les résultats ont montré que les tissus du système immunitaire du poisson zèbre comprenaient le rein de la tête, le thymus et la rate. Le rein de la tête était composé de tissu hématopoïétique contenant du sang et des cellules immunitaires. La rate était un organe unique situé dans la cavité abdominale contenant des mélano macrophages. Le thymus a été observé comme un organe apparié à la partie postérieure de la cavité branchiale. Les résultats ont montré que le système immunitaire du poisson zèbre était dispersé dans plusieurs organes du corps et que cette espèce pourrait être utilisée comme organisme modèle de laboratoire dans les études du système immunitaire.

REZUMAT: Studiu histologic al sistemului imunitar la peştele zebră, Danio rerio (Hamilton, 1822).

Scopul prezentului studiu a fost de a investiga caracteristicile celulare ale țesuturilor imune ale peștelui zebră, Danio rerio (Hamilton, 1822). Peștii au fost fixați în soluție Bouin timp de 24 de ore, apoi au fost deshidratați, curățați, parafinizați, încorporați și, în final, secționați, colorați și observați cu ajutorul microscopiei optice. Rezultatele au arătat că țesuturile sistemului imunitar ale peștilor zebră includ rinichiul anterior, timusul și splina. Capul rinichiului a fost compus din țesut hematopoietic conținând sânge și celule imune. Splina a fost singurul organ situat la nivelul cavității abdominale conţinând melanomacrofage. Timusul a fost observat ca un organ pereche în partea posterioară a cavităţii branhiale. Rezultatele au arătat că sistemul imunitar al peștilor zebră este dispersat în mai multe organe ale corpului și această specie ar putea fi folosită ca model de laborator în studiile sistemului imunitar. 


\section{INTRODUCTION}

The study and research of the immune system of aquatic organisms, including fish, leading biologists with the drive to understand the immune system process in fish which will help prevent and control aquatic diseases, especially those affecting ornamental and high economic value fish. These fish make up a large part of the fish trade. Ornamental fish are also of great importance to biologists because of their small size and usefulness in understanding the immune system of fish. The study of fish defence mechanisms and how the immune system works can be very effective in preventing, treating, and controlling aquatic diseases. Studying and recognizing the immune systems in a variety of fish can also lead to a reduction in the use of antibiotics in aquatic organisms, thus greatly reducing the side effects of these compounds on the human body and the environment. (Ghalambor et al., 2020)

Fish were the first vertebrates to possess both an innate and acquired immune system in the evolutionary pathway. Multiple studies have been conducted on the fish's immune system, showing that it is rather simple compared to higher vertebrates. The spleen, thymus, and kidney are regarded as being the major immune organs in fishes, albeit with slightly various roles between species. (Nasrullah et al., 2019)

Fish lymphoid organs are consistent with the thymus, apical part of the kidney, and spleen. Just after fertilization, lymphoid organs start their evolution in fish. A fish's innate immune system consists of physical barriers such as the skin epithelium, gills, mucosal layers, immune cells such as macrophages, granulocytes, natural killer cells, and soluble components such as lysozyme, agglutinins, perceptins (lectins and opsonins), anti-bacterial agents, and transporters (iron-binding proteins). In addition, the complement system and interferons are responsible for acquired immunity. (Salinas et al., 2011)

The Zebrafish, Danio rerio, has become an interesting biological model for safety analysis. This fish has many advantages over other biological models, including ease of testing, ease of prescribing drugs, and its fertility. Zebrafish is an exceptional laboratory model on which genetic studies have been used to identify or treat some human diseases. (Khoshnood, 2015)

The Zebrafish is a small, low-cost species with a high level of morphological, physiological and genetic coordination with the human genome. Modeling the human condition in Zebrafish makes it possible to discover potential therapeutic targets and their molecular conflicts. Therefore, in the present study, the cellular characteristics of the immune system tissues of this fish were investigated.

\section{MATERIAL AND METHODS}

\section{Fish}

Zebrafish, Danio rerio (2.3-3 cm total body length) was purchased from an ornamental fish breeding center in Dezful, Khuzestan, Iran, and transported to the laboratory in plastic bags containing aerated fresh water. The fish were anesthetized and sacrificed with a solution of clove powder, then immediately transferred to storage solutions for the next steps.

\section{Histology}

For the histological study, 10 fish were euthanized and the whole body was immediately immersed into Bouin's fixative for $24 \mathrm{~h}$, rinsed, and dehydrated in an ascending series of ethanol, followed by butanol and xylene for embedding in paraffin (Merck). Following embedment in paraffin, transversal, and longitudinal sections of six $\mu \mathrm{m}$ were cut on a Leica RM2255 microtome and collected on glass slides consecutively (all sections were collected) and stained with hematoxylin and eosin (Khoshnood, 2015, 2017). 


\section{RESULTS AND DISCUSSION}

Histological study of Zebrafish showed that the tissues involved in the immune system of this fish include the apical part of the kidney, thymus, and spleen. The results showed that the kidney is composed of two parts: the apical part of the kidney and trunk. The apical part of the kidney is clearly composed of hematopoietic tissue and the trunk portion consists of glomeruli and renal tubules. In the hematopoietic section of the apical part of the kidney, melanoma macrophages were visible along with other blood cells being produced. Melanoma macrophages were phagocytic cells containing various pigments such as melanin (brownblack) that were observed in the hematopoietic tissue of the apical part of the kidney (Fig. 1).

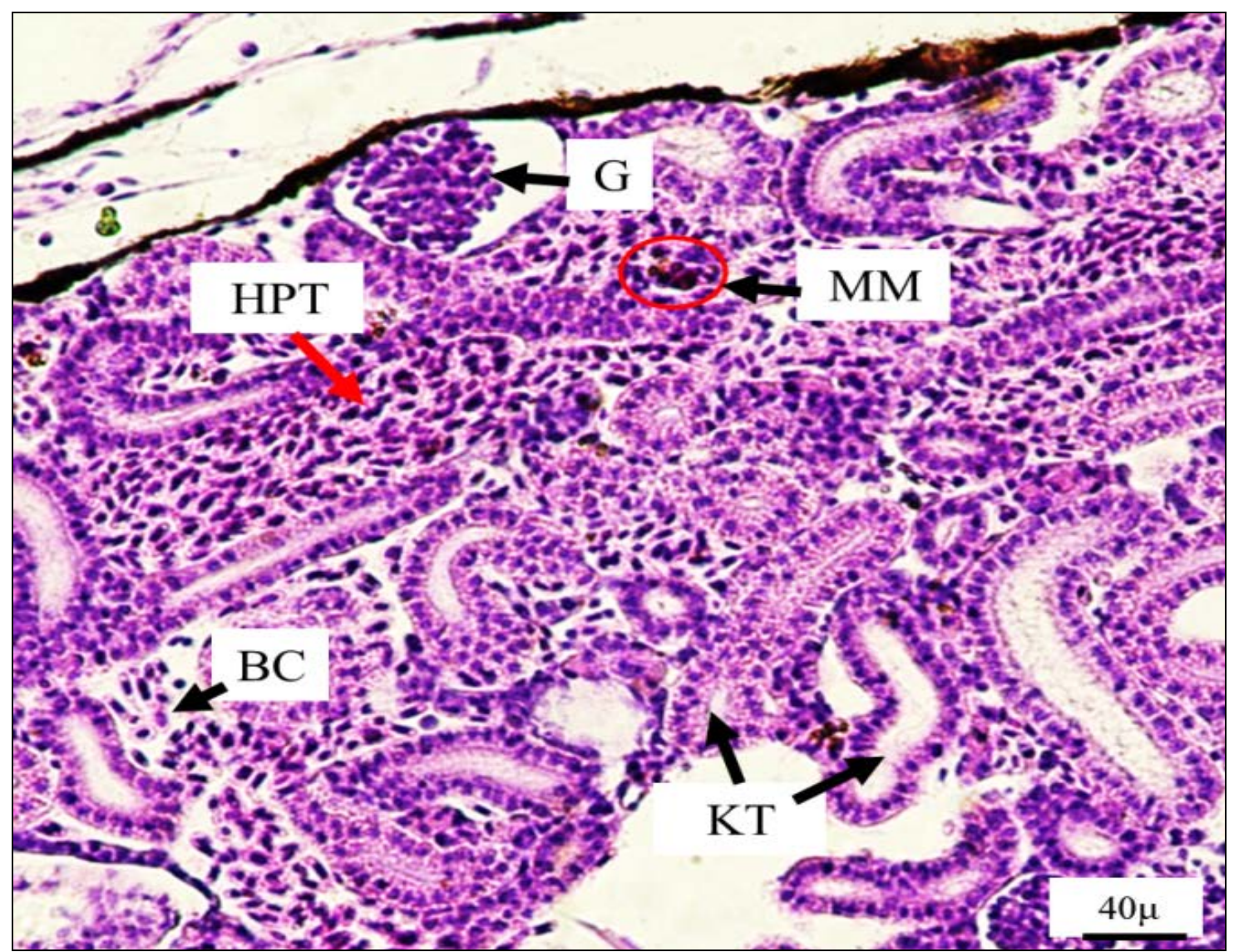

Figure 1: Histology of the apical part of the kidney in Zebrafish, Danio rerio, which consists of hematopoietic tissue and renal tubules. Items seen in the image: HPT: Hematopoietic Tissue; G: Glomeruli; MM: Melano-Macrophage; BC: Blood Cell; KT: Kidney Tubule.

The spleen was a single organ in the abdominal area attached to the gastrointestinal tract. Blood vessels, white pulp and red pulp were observed in the spleen tissue. The limb was covered by a thin capsule of connective tissue. The red pulp contained a large portion of the spleen, including sinusoids and blood cells, and formed the bulk of splenic tissue. The white pulp was composed mainly of lymphocytes that had accumulated around the blood vessels (Fig. 2). 
The thymus was observed as a pair of organs in the posterior part of the gill cavity. Epithelial-like cells formed the thymus parenchyma that provided a scaffold for thymocytes. Two regions of the cortex, including thymocytes and the medulla (central part), which were composed mostly of epithelial cells, were observed (Fig. 3).

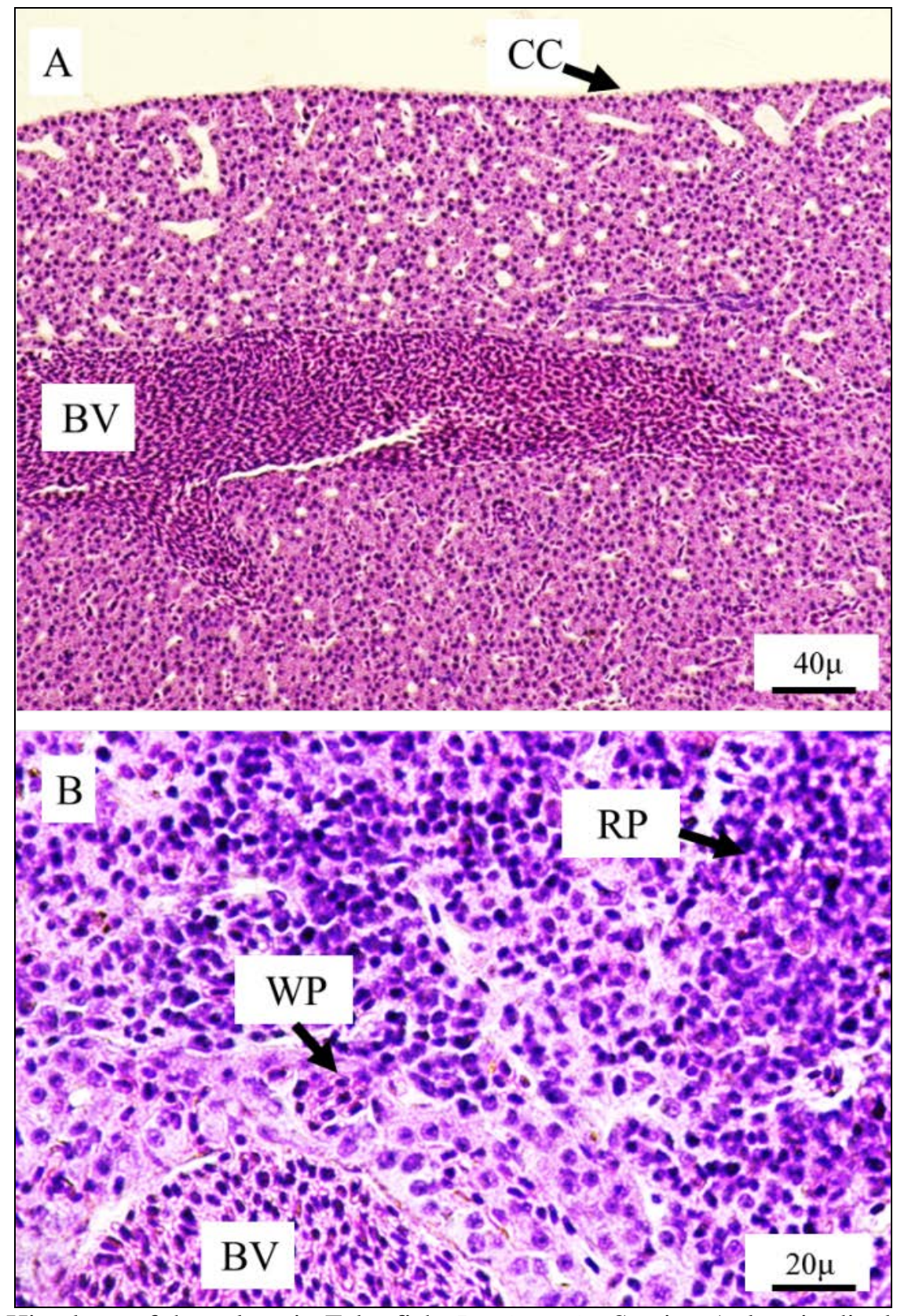

Figure 2: Histology of the spleen in Zebrafish, Danio rerio. Section A: longitudinal section of the spleen in which blood vessel (BV) and connective tissue capsule (CC) are visible. Section B: enlargement of spleen tissue with white pulp (WP - pink), red pulp (RP - purple) and blood vessels (BV). Items seen in the image include: connective tissue capsule (CC); white pulp (WP); red pulp (RP); blood vessel (BV). 


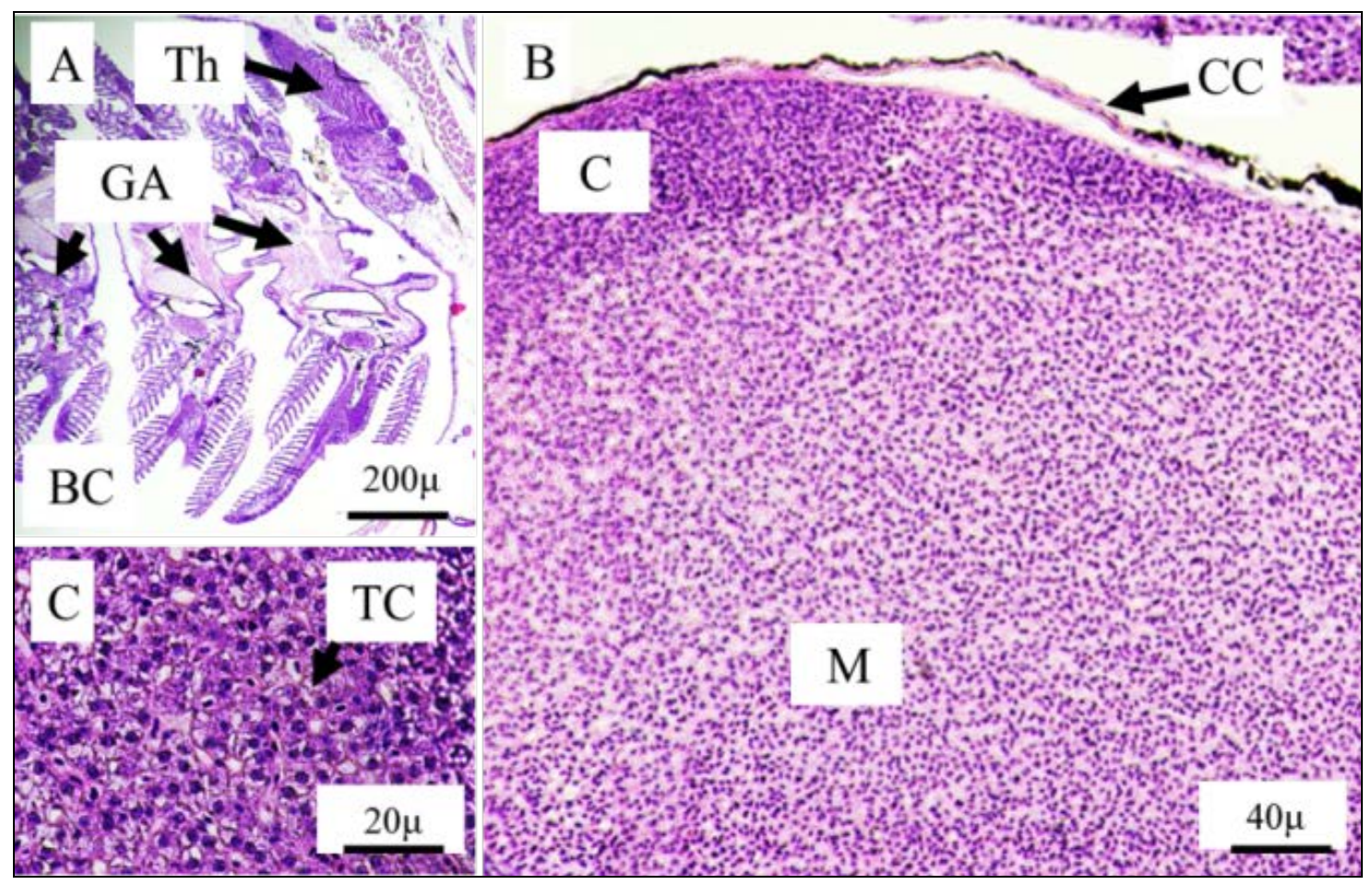

Figure 3: Histology of the thymus in the Zebrafish, Danio rerio.

Section A: position of thymus tissue in the dorsal part of the gill cavity. Section B: two sections of cortex (C) and medulla (M) are seen along with connective tissue capsules. Section C: a close-up of the thymocytes (TC) cells that make up thymus tissue. Items seen in the image include: connective tissue capsule (CC); thymus (Th); gill arch (GA); branchial cavity (BC); cortex (C); medulla (M); thymocyte (TC).

The fish immune system consists of innate as well as acquired responses, both of which protect against pathogens. Immune responses are also divided into two groups: cellular and humoral. Various factors, including lymphocytes, macrophages, neutrophils, cytokines, immunoglobulin, and the complement system, play a role in these responses. Since fish immune system responses rely primarily on innate immunity, macrophages play the most important role in this system (Nayak, 2010). In addition to the role of these cells in the production of cytokines, macrophages are responsible for phagocytosis and the killing of invasive and foreign cells (Boshra et al., 2006). The results of the present study showed that the immune system of Zebrafish, Danio rerio, as an ornamental freshwater fish, consisted of the thymus, spleen, and apical part of the kidney. Various studies have shown that the most important organs and tissues involved in the immune system of fish include the thymus, spleen, and kidneys (Bowden et al., 2005).

Previous studies have shown that the spleen is responsible for purifying the blood of old and worn out blood cells, especially red blood cells. This activity takes place mainly in the red pulp of the spleen. White pulp, on the other hand, is a site of accumulation of lymphoblasts, lymphocytes, macrophages, platelets, adult and immature neutrophils, and eosinophils, which are well described in striped bass (Hanington et al., 2009). 
The liver is generally covered by a thin connective tissue capsule that has protractions to the liver tissue. Liver lobules are not distinctive and enclosed areas, which is generally dependent on the fish species. (Khoshnood, 2017)

The thymus, kidney, and the spleen are the largest lymphoid organs in fish. Thymic structure, in contrast to the higher vertebrates, is highly variable and also in multiple species, it is not easy to clearly distinct between the cortex and the medulla. The apical part of the kidney in fish has the same role of bone marrow in higher vertebrates and is the main site of hematopoiesis. The main immune cells found in the apical part of the kidney are macrophages, which aggregate into so-called melanomacrophage centers and lymphoid cells especially the B cells, which are found at all developmental stages (Rodrigues et al., 2020).

All organisms have defence mechanisms against pathogens and free radicals. Among these defence mechanisms are antioxidant enzymes that remove oxidative stress products such as free radicals and reactive oxygen species. Any disturbance in these defence systems can upset the balance of the living body. Catalase and superoxide dismutase enzymes are among the most important antioxidant enzymes. The first defence barrier for aquatic organisms under stressful conditions are antioxidant enzymes, the study of which can lead to a better understanding of the immune system's defence processes. Lysozyme is present in many vertebrates and is mainly produced by white blood cells. Lysozyme has been studied in mucus secretions, renal gill spleen, serum and the gastrointestinal tract of various organisms. Lysozyme, along with TNF $\alpha$, plays an important role in fish immune responses (Ghalambor et al., 2020). Previous studies have shown that lysozyme is secreted by white blood cells and is found in mucus, gills, kidney, spleen, gastrointestinal, and serum secretions and can break the glycosidic bonds of the peptidoglycan layer of gram-positive bacteria (Nayak, 2010).

\section{CONCLUSIONS}

The results of the present study showed that zebrafish, Danio rerio, had a complete immune system consisting of the main immune organs of the spleen, thymus, and apex of the kidney. This shows that zebrafish have protection against pathogens and destructive factors. The results also showed that the immune system of this fish species is scattered in different organs of the body and the pattern of this distribution and the structure of these tissues involved in the immune system is similar to other bony fish. 


\section{ACKNOWLEDGEMENTS}

The authors are willing to thank Dr. Nargess Monjezi for her valuable help during experimental work. 


\section{REFERENCES}

1. Boshra H., Li J. and Sunyer J. O., 2006 - Recent advances on the complement system of teleost fish, Fish and Shellfish Immunology, 20, 239-262.

2. Bowden T. J., Cook P. and Rombout J. H., 2005 - Development and function of the thymus in teleosts, Fish and Shellfish Immunology, 19, 413-427.

3. Ghalambor M., Eslamifar Z. and Khoshnood Z., 2020 - Biochemical characterization of lysozyme extracted from common carp, Cyprinus carpio, Ecopersia, 8, 2, 125-131.

4. Hanington P. C., Tamb J., Katzenback B. A., Hitchen S. J., Barreda D. R. and Belosevic M., 2009 - Development of macrophages of cyprinid fish, Developmental and Comparative Immunology, 33, 411-429.

5. Khoshnood Z., 2015 - Histopathological alterations in the kidney of Caspian kutum, Rutilus frisii kutum, larvae and fingerlings exposed to sublethal concentration of atrazine, Bulletin of Environmental Contamination and Toxicology, 94, 158-163.

6. Khoshnood Z., 2017 - Histopathological alterations in the digestive system of Rutilus frisii kutum (Kamensky, 1901) fry after exposure to atrazine herbicide, Romanian Journal of Biology - Zoology, 62, 1-2, 73-86.

7. Nasrullah H., Nababan Y. I., Yanti D. H., Hardiantho D., Nuryati S., Zairin M., Ekasari J. and Alimuddin A., 2019 - Identification and expression analysis of c-type and g-type lysozymes genes after Aeromonas hydrophila infection in African catfish, Jurnal Akuakultur Indonesia, $18,2,1-10$.

8. Nayak S. K., 2010 - Probiotics and immunity: A fish perspective, Fish and Shellfish Immunology, 29, 2-14.

9. Rodrigues M. V., Zanuzzo F. S., Koch J. F. A., de Oliviera C. A. F., Sima P. and Vetvicka V. Development of fish immunity and the role of $\beta$-Glucan in immune responses, Molecules, 25, 5378.

10. Salinas I., Zhang Y. A. and Sunyer J. O., 2011 - Mucosal immunoglobulins and B cells of teleost fish, Developmental and Comparative Immunology, 35, 1346-1365. 